\title{
The action of yeast strains as biocontrol agents against Penicillium digitatum in Lima sweet oranges
}

\author{
Tatiane da Cunha ${ }^{1}$, Luriany Pompeo Ferraz ${ }^{1}$, Gilmar da Silveira de Sousa-Júnior ${ }^{2}$ \& \\ Katia Cristina Kupper ${ }^{1,3}$
}

\begin{abstract}
SUMMARY
The green mold caused by Penicillium digitatum is the most important disease affecting citrus in the postharvest period. An alternative to control the disease lies on the use of yeasts. The purpose of the present study was to assess the ability of 101 yeasts strains to control $P$. digitatumin vitro and in vivo. The assay followed a randomized design with five repetitions and the evaluation took into consideration the mean pathogen colony diameter in Petri dish paired culture. In addition, the effect of the fungus on yeast strain growth was assessed. Orange fruits (Citrus sinensis cv. Lima) were injured in two equidistant points and inoculated with $P$. digitatum conidia suspension 24 hours before and after treatments, in the assays conducted in vivo. Treatments consisted in the application of eight yeast suspensions, fungicide and distilled water (control treatment); they followed a randomized design with three repetitions (20 fruits per repetition). The best antagonist results in vitro were recorded for five strains (Saccharomyces cerevisiae ACBL-76 and ACBL-82 strains; Candida stellimalicola ACBL-84 strain; and ACBL-87), which presented mycelial growth inhibition values higher than $80 \%$. Two yeast strains ( $S$. cerevisiae ACBL- 82 strain and Meyerozyma caribbica ACBL-86 strain) have successfully controlled the progress and incidence of green mold in orange fruits when they were applied in a preventive manner.
\end{abstract}

Index terms: green mold, antagonist yeasts, biological control, postharvest, Citrus sinensis.

\section{Utilização de isolados de leveduras em laranjas Lima para o biocontrole de Penicillium digitatum}

\section{RESUMO}

O bolor verde ocasionado pelo Penicillium digitatum é a doença mais importante que afeta frutos de citros na pós-colheita. Uma alternativa para controlar a doença é por meio da utilização de leveduras. O objetivo desse estudo foi avaliar a capacidade de 101 isolados de leveduras no controle in vitro e in vivo de $P$. digitatum. O screeningin vitro foi conduzido por meio da técnica de cultivo pareado em placa de Petri. O ensaio foi realizado com delineamento inteiramente casualizado, com cinco repetições por tratamento e a avaliação feita por meio da aferição do diâmetro médio da colônia do fitopatógeno. Além disso, também foi avaliado o efeito do fungo no crescimento

\footnotetext{
${ }^{1}$ Faculdade de Ciências Agrárias e Veterinárias - FCAV, Universidade Estadual Paulista - UNESP, Jaboticabal, SP, Brasil

${ }^{2}$ Centro de Ciências Agrárias - CCA, Universidade Federal de São Carlos - UFSCar, Araras, SP, Brasil

${ }^{3}$ Centro de Citricultura "Sylvio Moreira" - CCSM, Instituto Agronômico de Campinas - IAC, Cordeirópolis, SP, Brasil

Corresponding author: Katia Cristina Kupper, Centro de Citricultura "Sylvio Moreira" - CCSM, Instituto Agronômico de Campinas - IAC, Rodovia Anhanguera, km 158, CP 04, CEP 13490-970, Cordeirópolis, SP, Brasil. E-mail: katia@ccsm.br
} 
dos isolados de leveduras. Para os ensaios conduzidos in vivo, frutos de laranja (Citrus sinensis cv. Lima) foram feridos em dois pontos equidistantes e inoculados com uma suspensão de conídios de $P$. digitatum, 24 horas antes e após os tratamentos. Os tratamentos consistiram na aplicação de suspensões de levedura, fungicida (tratamento negativo) e água destilada (tratamento controle); com três repetições por tratamento (20 frutos por repetição). Cinco isolados de leveduras obtiveram os melhores resultados in vitro (Saccharomyces cerevisiae- ACBL-76 e ACBL-82; Candida stellimalicola-ACBL-84 e ACBL-87), com valores de inibição do crescimento micelial superiores a 80\%. Dois isolados de levedura (S. cerevisiae- ACBL-82 e Meyerozyma caribbica - ACBL-86) diminuíram o progresso e a incidência de bolor verde em frutos de laranja quando aplicados preventivamente.

Termos de indexação: bolor verde, levedura antagonista, controle biológico, pós-colheita, Citrus sinensis.

\section{INTRODUCTION}

Citrus fruits are the top fruit crop in international trade; China and Brazil have the largest citrus production in the world (Liu et al., 2017). Injuries caused in fruits during harvesting and transportation processes are gateways to the fungus Penicillium digitatum, which is the causal agent of green mold and the most economically important postharvest disease affecting citrus. Green mold reduces the quality and quantity of citrus fruits, besides damaging nutritional and market values (Plaza et al., 2004).

Hitherto, chemical treatments, such as synthetic fungicides Imazaliland Thiabendazole, have customarily been used to control the disease (Sun et al., 2013). Environmental and human health concerns, as well the emergence of pathogen strains resistant to these chemicals, have boosted the search for alternative control measures, such as biocontrol based on yeasts, to prevent or reduce citrus diseases (Zhu et al., 2006; Kinay et al., 2007; Spadaro \& Droby, 2016; Liu et al., 2017).

The purpose of expanding citrus fruit exports and growing market lies on the acquisition of pesticide residue-free fruits; thus, biological control based on the application of antagonist microorganisms plays a major role among the alternative methods adopted to control several diseases affecting fruits and vegetables. Recent studies have investigated the use of yeasts to control fungal diseases in the postharvest period (Platania et al., 2012; Kupper et al., 2013; Moretto et al., 2014; Ferraz et al., 2016; Liu et al., 2017).

With respect to the microbial control field, yeasts have characteristics that make them promising pathogenic fungi-biocontrol agents, mainly because they rarely produce mycotoxins or antibiotic substances that could leave residues in fruits (Droby et al., 2002; Gamagae et al., 2004; Zhang et al., 2005). The use of yeasts in biological control programs has encouraged the development of commercial yeast-based biocontrol products to treat postharvest diseases affecting fruits; among them, one finds Candida oleophila (I-182 strain), which is used to treat postharvest citrus diseases (Liu et al., 2013).

Nevertheless, the quest for identifying new yeast strains capable of thriving in different environments through new action modes remains because food security requires new biocontrol alternatives to help managing postharvest citrus diseases. Therefore, the current study has investigated yeast strains with potential to control green mold disease affecting citrus fruits by assessing their antagonist behavior towards $P$. digitatum in vitro and in vivo. The current results make a relevant contribution to the growing scientific literature about the use of yeast-based products as alternative sources to protect fruits against pathogens in post-harvest management processes.

\section{MATERIAL AND METHODS}

\section{Pathogen and growth conditions}

The pathogen (Penicillium digitatum) used in the current study was obtained in the microorganism collection of Centro de Citricultura "Sylvio Moreira" (IAC), Cordeirópolis County, SP, Brazil. The fungus was grown in potato-dextrose-agar (PDA) for 7-10 days and cultures were incubated in BOD (Biochemical Oxygen Demand) chamber at $25^{\circ} \mathrm{C}$ for 3-7 days, under $12 \mathrm{~h}$ photoperiod, and kept in PDA medium within test tubes for further testing. Before it was use, the pathogen was monitored under bright field (Leica Microsystems Co., Wetzlar, Germany) microscope, at $400 \times$ magnification, in order to observe vegetative conidia. Standardized conidia suspension concentrations were adjusted in Neubauer chamber, after serial dilutions. 


\section{Yeast strains}

The herein performed assays used 101 yeast strains. Six Saccharomyces cerevisiae strains (ACB-BG1, ACB-CAT1, ACB-CR1, ACB-K1, ACB-KD1, and ACB-PE2) were obtained from ethanol fermentation; they were characterized by karyotyping electrophoresis and kept in the Collection of the Biochemistry and Plant Pathology Laboratory at University of São Paulo (ESALQ), Piracicaba County, SP, Brazil (Fialho et al., 2010). The others yeasts (95 strains) were obtained from citrus leaves, flowers, fruits and soil from São Paulo citrus belt; seven strains were identified by our group based on the sequencing of ITS regions of the rDNA (five strains of Saccharomyces cerevisiae - ACBL-76, ACBL-78, ACBL-80, ACBL-81, and ACBL-82 strains; one strain of Candida stellimalicola - ACBL-84 strain; and one strain of Meyerozyma caribbica - ACBL-86 strain) (Ferraz et al., 2018) and they were kept in the Microorganism Collection of Centro de Citricultura "Sylvio Moreira" (IAC), Cordeirópolis County, SP, Brazil.

Cultures were grown in YEPD medium (yeast extract peptone dextrose $-1 \%$ yeast extract, $2 \%$ peptone, $2 \%$ glucose, $2 \%$ agar, $0.01 \%$ ampicillin, and $0.01 \%$ nalidixic acid dissolved in 1 liter of distilled water), incubated in BOD chamber at $25^{\circ} \mathrm{C}$, for 3-7 days, under $12 \mathrm{~h}$ photoperiod, and kept in YEPD medium within test tubes for further testing.

\section{Screening the antifungal activity in vitro of yeast strains}

The paired cultivation technique in Petri dishes (Dennis \& Webster, 1971) was used to assess the antagonistic capacity of all 101 yeast strains against $P$. digitatum. Disks ( $5 \mathrm{~mm}$ diameter) were removed from active $P$. digitatum colonies grown in PDA for 7-10 days and placed in Petri dishes containing PDA culture medium, $3 \mathrm{~cm}$ away from disks containing 1 strain of each yeast ( $5 \mathrm{~mm}$ diameter) grown in YEPD medium for 48 hours. The control group comprised fungi growth without yeast addition. The experiment followed a completely randomized design with four repetitions for each of the 5 trials. Data were subjected to analysis of variance (ANOVA). Means were tested through the Scott-Knott test $(P<0.05)$.

In addition, the effect of $P$. digitatum on the vegetative growth of 101 yeast strains colonies was assessed based on the paired cultivation technique applied in Petri dishes; however, for this assay, we assessed the colony growth of each yeast strain cultivated with the fungus. Control treatment corresponded to yeasts strains colony growth without the fungus (adapted from Dennis \& Webster, 1971). This assay followed a completely randomized design with two repetitions. The average of colonies diameter from yeasts strains were subjected to analysis of variance (ANOVA) with two-factor factorial design and means were compared to each other through the Scott-Knott test $(P<0.05)$.

\section{Antifungal activity in vivo}

Based on the methodology described by Ferraz et al. (2016), Lima sweet orange fruits [Citrus sinensis (L.) Osbeck] at commercial ripening stage were obtained in a packinghouse located in Limeira County, São Paulo State, Brazil. Orange fruits (without treatment) were superficially disinfected with $0.2 \%(\mathrm{v} / \mathrm{v})$ sodium hypochlorite for 3 minutes and, later, they were washed with distilled water. Sterile needles were used to injure the fruits ( $3 \mathrm{~mm}$-deep) at two equidistant points in their median region; next, the wounded area was inoculated with $20 \mu \mathrm{L}$ of $P$. digitatum conidia suspension $\left(1.0 \times 10^{5}\right.$ conidia $\left.\mathrm{mL}^{-1}\right)$ and treated with the yeast (curative treatment) 24 hours later. As for the preventive treatment, the fruits were wounded, treated with the yeast and inoculated with the pathogen, 24 hours later.

Eight yeast strains (Saccharomyces cerevisiae - ACBL-76, ACBL-78, ACBL-80, ACBL-81, and ACBL-82 strains; Candida stellimalicola - ACBL-84 strain; Meyerozyma caribbica - ACBL-86 strain; and ACBL-87) were selected based on screening in vitro in order to compose the treatments applied in assays conducted in vivo. Treatments were prepared based on the methodology by Ferraz et al. (2016); yeast strain suspensions were adjusted to $1.0 \times 10^{7}$ cells $\mathrm{mL}^{-1}$. The fungicide Imazalil was used as negative control, based on the manufacturer's recommendations to control green mold $(200 \mathrm{~mL} / \mathrm{L})$. Fruits treated with sterile distilled water were used as positive control.

Inoculated and treated fruits were stored for seven days at room temperature $\left(22{ }^{\circ} \mathrm{C} \pm 2,80 \% \mathrm{RH}\right.$, and $12 \mathrm{~h}$ photoperiod). Disease severity was assessed on the $5^{\text {th }}, 6^{\text {th }}$ and $7^{\text {th }}$ day after inoculation by measuring the diameter of green mold lesions with a caliper. The incidence of the disease was assessed based on the percentage of infected fruits observed at the $7^{\text {th }}$ day after inoculation. Treatments of the assays conducted in vivo followed a completely randomized design, with three repetitions per treatment and 20 fruits per repetition. The effect of the treatments on the mean size of the lesions caused by 
$P$. digitatum was analyzed based on the area under the disease progress curve (AUDPC), which was calculated and expressed by plotting the disease proportion as percentage versus time. According to Shaner \& Finney (1977), the AUDPC can be calculated based on the following formula:

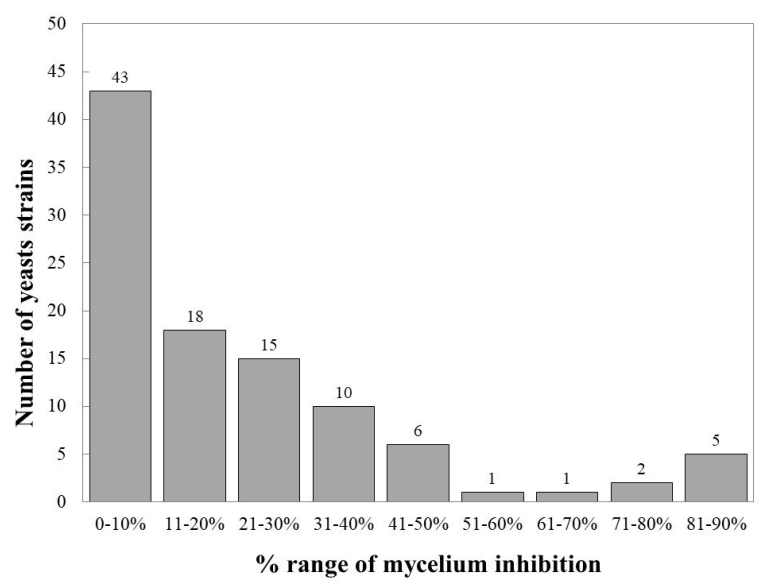

Figure 1. In vitro screening of the yeasts strains by antifungal activity against Penicillium digitatum. Number of yeasts strains assessed in vitro ( $y$-axis). Range of mycelium inhibition ( $x$-axis).
$A U D P C=\sum^{n-1}\left[\left(Y_{i+1}+Y_{i}\right) / 2\right] *\left[\left(T_{i+1}-T_{i}\right)\right]$

wherein: $\mathrm{n}$ is the number of observations/evaluations; Yi is the disease proportion in the " $\mathrm{i}$ "-th observation/evaluation; and $\mathrm{Ti}$ is the time (in days) in the " $\mathrm{i}$ "-th observation/evaluation;

Results were subjected to analysis of variance (ANOVA) in the Assistat 7.7 beta software and means were compared to each other through Tukey test $(P<0.05)$.

\section{RESULTS}

\section{Antifungal activity in vitro}

The screening in vitro of 101 yeast strains (Figure 1) has shown that 14 yeast strains were capable of inhibiting $P$. digitatum mycelial growth up to $45 \%$. Five strains inhibited more than $80 \%$ of $P$. digitatum mycelial growth; they are herein presented based on their increasing order of inhibition power: ACBL-82, ACBL-86, ACBL-84, ACBL-76, and ACBL-87. Three strains (ACBL-81, ACBL-78, and ACBL-80) inhibited $P$. digitatum mycelial growth by $60-79 \%$ (Figure 2). Therefore, these eight best strains were selected for the assays conducted in vivo.

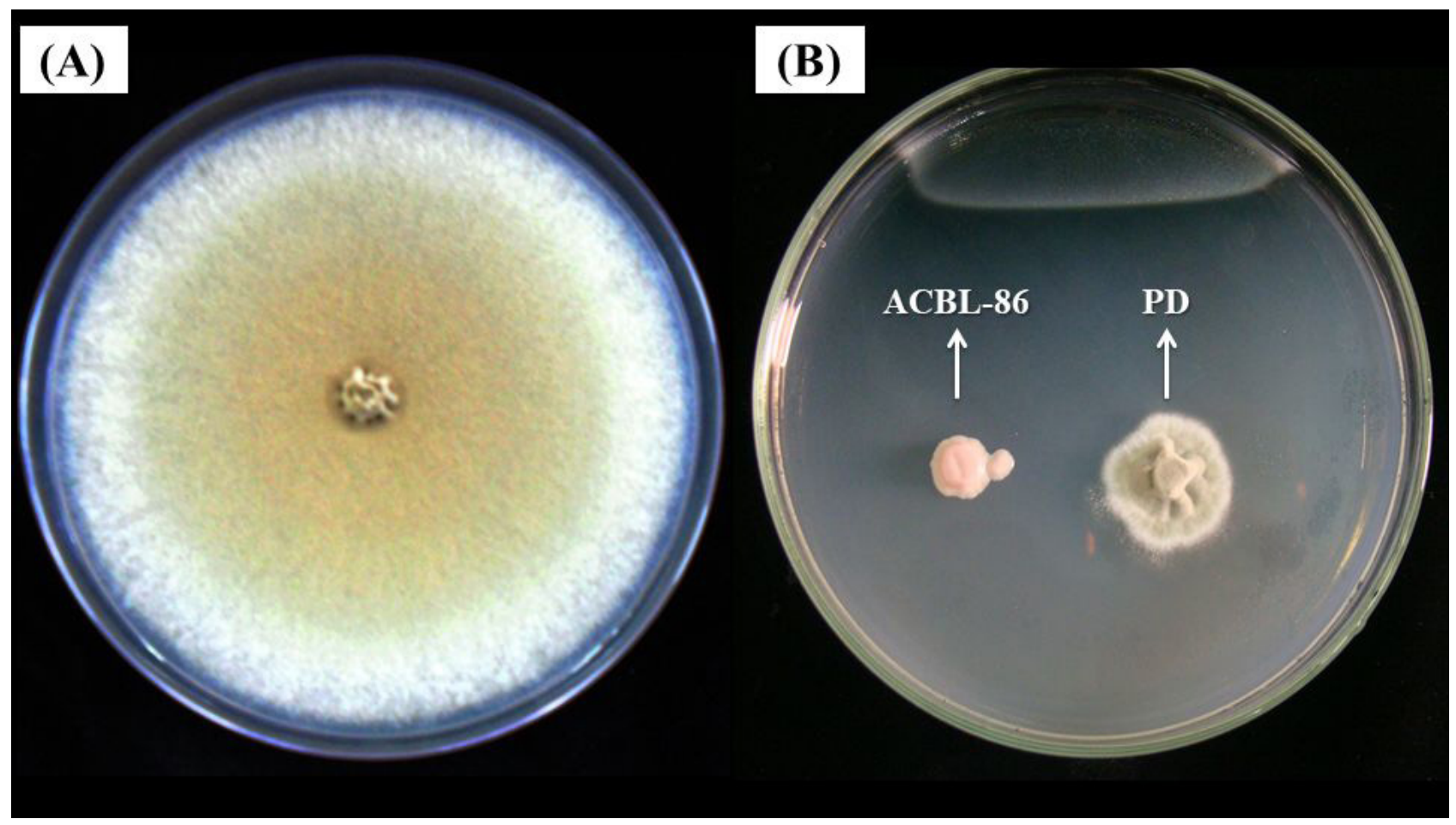

Figure 2. In vitro antagonism of Saccharomyces cerevisiae - ACBL-86 strain (B), with $83 \%$ inhibition of $P$. digitatum colony (PD) by paired cultivation technique in Petri dishes, after seven days storage at $25^{\circ} \mathrm{C} \pm 2$ and $12 \mathrm{~h}$ photoperiod. $P$. digitatum colony without yeast strain (control) (A). 
The effect of $P$. digitatum on the growth of all 101 yeast strains was assessed and the fungus was capable of inhibiting the vegetative growth of 24 strains up to $35 \%$ (Figure 3 ). The colony growth of six strains (ACLB-39, ACLB-51, ACLB-76, ACLB-83, ACLB-84, and ACB-KD1) was stimulated when they were cultivated along with the fungus. Among these yeast strains, ACBL- 76 was also capable of inhibiting pathogen growth in assays conducted in vitro -by up to $88 \%$, as demonstrated in the above assay by evaluation of antifungal activity in vitro (Figure 1).

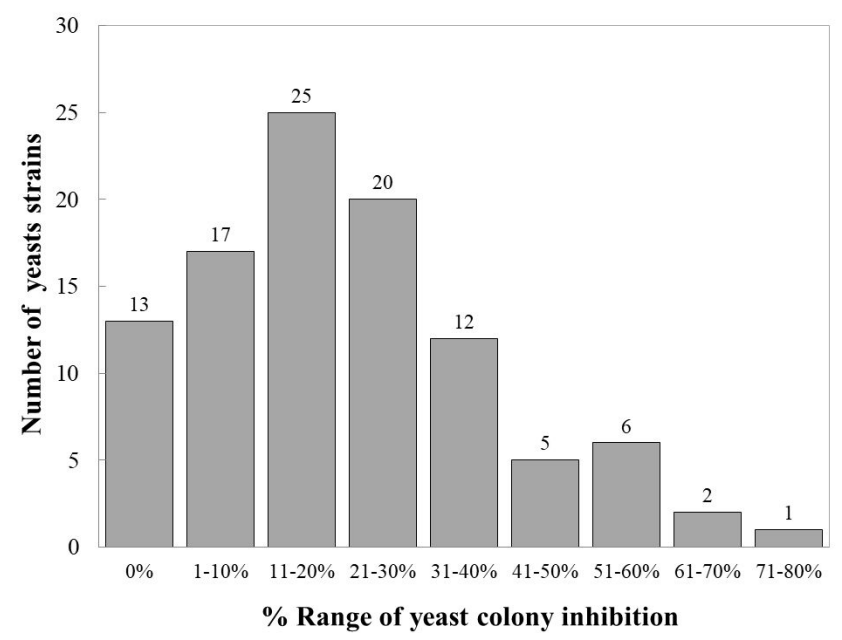

Figure 3. Influence of $P$. digitatum on the yeast isolates colony's growth in paired cultivation. Number of yeasts strains assessed in vitro ( $y$-axis). Range of inhibition of yeasts colonies ( $x$-axis).

\section{Effect of yeast treatments on the progress of green mold disease affecting Lima sweet orange fruits}

Three yeaststrains-ACBL-86(11.9mm),ACBL-82(19.2 mm) and ACBL-80 (22.8 mm) (Figure 4A) -reduced the development of the mean size of fruit lesions when Lima sweet oranges were preventively treated. Among the curative treatment trials, only the negative treatment (Imazalil) reduced the progress of green mold disease (Figure 4B). However, results recorded for strains ACBL-86, ACBL-82 and ACBL-80 were statistically similar to that of the fungicide, when these strains were preventively used (Figure 4A).

\section{Effect of treatments on the incidence of green mold in Lima sweet orange fruits}

Yeast strains ACBL-86 and ACBL-82 enabled lower disease incidence control when fruits were preventively treated (Figure 5); they inhibited by $42 \%$ and $28 \%$ the incidence of symptomatic fruits, respectively (Figure 6A). The negative control (Imazalil) enabled 100\% healthy fruits when it was used in a preventive manner. Yeast strains used in the curative treatment trials was not effective in controlling the disease (Figure 6B).

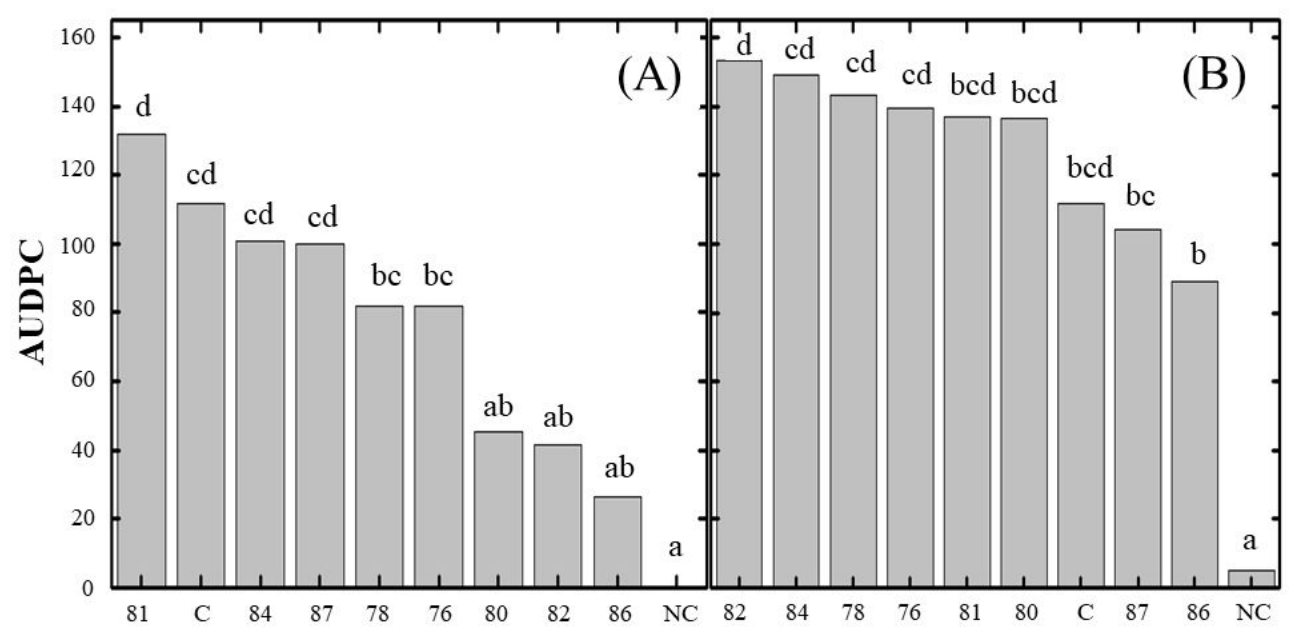

Figure 4. Area under the disease-progress curve (AUDPC) for average diameter of lesion caused by P. digitatum, after preventive (A) and curative (B) treatment with yeast strains, stored $\left(22{ }^{\circ} \mathrm{C} \pm 2\right.$ and $\left.90 \% \mathrm{RH}\right)$ for seven days ( $y$-axis). Mean values marked with the same lowercase letter are not significantly different according to Tukey's test $(P<0.05)$. $(x$-axis): The number corresponds to the yeast biological control agents $(\mathrm{ACBL})(x$-axis $) ; \mathrm{C}=$ control: distilled water; $\mathrm{NC}=$ negative control - Imazalil. 

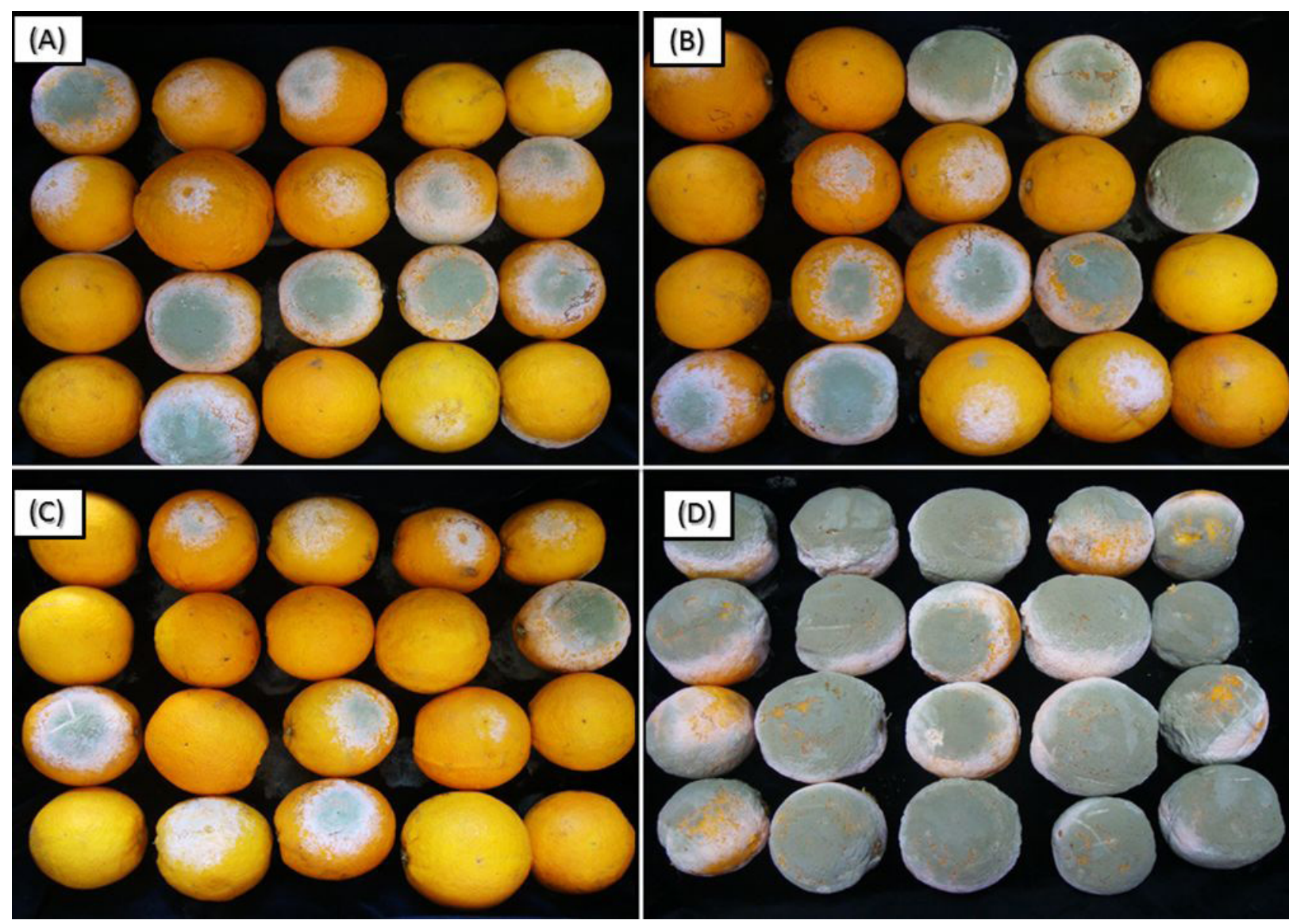

Figure 5. Lima sweet oranges after preventive treatments application and inoculation with $P$. digitatum. Fruits stored for seven days at $22{ }^{\circ} \mathrm{C} \pm 2$ and $90 \%$ RH. Yeast strains treatments (A) ACBL-80 (Saccharomyces cerevisiae); (B) ACBL-82 (S. cerevisiae) and (C) ACBL-86 (Meyerozyma caribbica); (D) Control: fruits treated with sterile distilled water with green mold symptoms

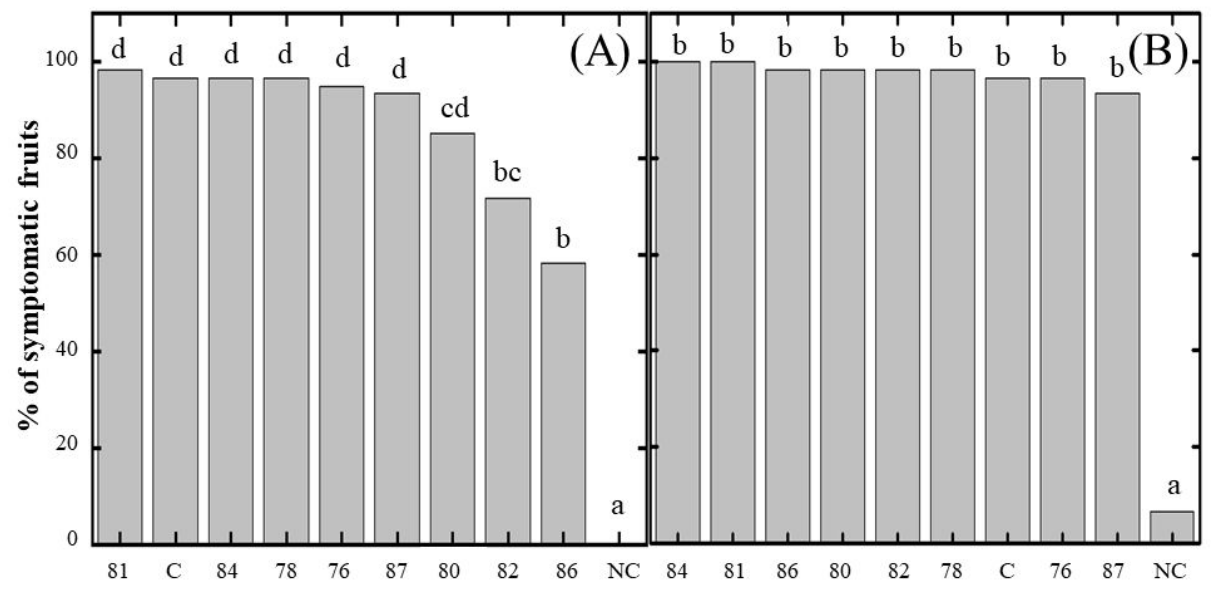

Figure 6. Percentage of Lima orange fruits with green mold symptoms after preventive (A) and curative (B) treatment with different yeast isolates, stored $\left(22{ }^{\circ} \mathrm{C} \pm 2\right.$ and $\left.90 \% \mathrm{RH}\right)$ for seven days ( $y$-axis). Means values marked with the same lowercase letter are not significantly different according to Tukey's test $(P<0.05)$. ( $x$-axis): The number corresponds to the yeast biological control agents $(\mathrm{ACBL})(x$-axis); $\mathrm{C}=$ control: distilled water; $\mathrm{NC}=$ negative control - Imazalil. 


\section{DISCUSSION}

Several steps are required to obtain a biological control agent, which involve the isolation and selection of different microorganisms in order to find strains with desirable features used to formulate commercial products (Droby et al., 2009). The current study selected yeasts with potential to enable the biocontrol of $P$. digitatum.

Previous studies have demonstrated that phylloplane was the main source used to obtain yeast isolates; most yeast strains used in the current study were isolated from citrus leaves, flowers and fruits (Ferraz et al., 2018). Similar to other studies conducted with yeasts isolated from citrus phylloplane, antagonist yeasts have shown potential to control Penicillium italicum (Liu et al., 2017; Cunha et al., 2018) and P. digitatum (Perez et al., 2017; Ghosh et al., 2018; Habiba et al., 2019). Indeed, leaf and fruit surfaces are suitable for the isolation of antagonistic microorganisms such as yeast strains, due to fast colonization enabled by high sugar contents found in these environments (Sharma et al., 2009; Liu et al., 2013).

The dual culture plate method was applied to all yeast strains in order to investigate their antagonistic behavior towards $P$. digitatum; $15 \%$ of the strains inhibited the mycelial growth of the fungus by at least $40 \%$. Five strains were capable of inhibiting more than $80 \%$ of pathogen mycelial growth (S. cerevisiaeACBL-82 strain, M. caribbica ACBL-86 strain, C. stellimalicola ACBL-84 strain, $S$. cerevisiae ACBL-76 strain, and ACBL-87). The current results are in compliance with other studies conducted in vitro, such as the one conducted by Mekbib et al. (2011), who found that three yeast strains (two Cryptococcus laurentii and one Candida sake) were capable of rapidly colonizing the surface of $P$. digitatum colonies, where they competed with the pathogen for nutrients and space.

Based on the effect of $P$. digitatum on the growth of yeast strains, it was possible seeing thatACBL-76 had its growth boosted by the presence of the fungus. In addition, the aforementioned yeast strain was capable of inhibiting the growth of the pathogen colony by up to $88 \%$. This outcome may indicate that the action mode of ACBL-76 against $P$. digitatum is based on factors such as the inhibition of fungal conidia germination, nutrient competition, killer activity, and chitinase production, as reported in previous studies conducted by our research group (Ferraz et al., 2018).

Yeast strains ACBL-86 (M. caribbica) and ACBL-82 (S. cerevisiae) decreased the severity, and prevented the incidence of green mold in Lima sweet oranges subjected to assays in vivo. Taqarort et al. (2008) reported fifteen yeast strains capable of reducing by more than $50 \%$ the incidence of $P$. digitatum in citrus fruits after seven incubation days at $25^{\circ} \mathrm{C}$. Yeast strain ABCL-86 inhibited by at least $42 \%$ the incidence of symptomatic fruits and reduced the development of green mold lesions, when it was used in a preventive manner in the current study. However, biocontrol agents alone cannot assure consistency and protection effect in comparison to the negative control (synthetic fungicide Imazalil). Overall, antagonistic microorganisms have shown great effectiveness variability, since their protective effect decreased as fruit ripening progressed. In addition, these microorganisms cannot often eradicate pre-existing or incipient fungal pathogens and/or do not prevent their sporulation (Moretto et al., 2014). Thus, the use of antagonistic microorganisms in combination with other biological, chemical or physical methods is one of the main alternatives to improve the biocontrol of postharvest diseases (Usall et al., 2008).

Based on the evaluation of yeast ability to control green mold in orange fruits assessed in the present study, two strains (ACBL-82 and ACBL-86) were capable of decreasing the progress, and the incidence, of the disease when they were used in a preventive manner. Physical postharvest treatments such as short hot water brushing, and low ultraviolet light irradiation doses, have demonstrated potential to control postharvest fruit diseases (Terao et al., 2015). In addition, the combination between antagonistic yeasts and different disease control methods has been more effective in reducing postharvest fruit decay, besides compensating limitations resulting from their individual use. Thus, this combination is a promising way to minimize the use of synthetic fungicides in postharvest treatments (Wisniewski et al., 2016; Terao et al., 2017). Therefore, yeast strains could be preventively used against $P$. digitatum as an alternative, or complementary, control method in citrus postharvest management processes.

Finally, the postharvest biocontrol of green mold based on epiphytic yeasts appears to be a promising alternative to the use of synthetic fungicides, since it has less negative impact on human health and on the environment. Hence, it is necessary conducting further studies with yeast strains ACBL-82 and ACBL-86 in order to assess their ability to prevent $P$. digitatum colonization in fruit wounds treated with commercial formulations, as well as to investigate whether it is necessary combining the use of these yeasts with other methods in order to control green mold disease. 


\section{REFERENCES}

Cunha, T., Ferraz, L. P., Wehr, P. P., \& Kupper, K. C. (2018). Antifungal activity and action mechanisms of yeasts isolates from citrus against Penicillium italicum. International Journal of Food Microbiology, 276, 20-27.

Dennis, C. E., \& Webster, J. (1971). Antagonistic properties of species groups of Trichoderma III. Hyphal interactions. Transactions of the British Mycological Society, 57(1), 359-363.

Droby, S., Vinokur, V., Weiss, B., Cohen, L., Daus, A., Goldschmidt, E. E., \& Porat, R. (2002). Induction of resistance to Penicillium digitatum in grapefruit by the yeast biocontrol agent Candida oleophila. Phytopathology, 92(4), 393-399.

Droby, S., Wisniewski, M., Macarisin, D., \& Wilson, C. (2009). Twenty years of postharvest biocontrol research: Is it time for a new paradigm? Postharvest Biology and Technology, 52(2), 137-145.

Ferraz, L. P., Cunha, T., \& Kupper, K. C. (2018). Mecanismos de ação de isolados de leveduras envolvidos no biocontrole de Penicillium digitatum, agente causal do bolor verde em frutos cítricos. Citrus Research \& Technology, 39, e-1034.

Ferraz, L. P., Cunha, T., Silva, A. C., \& Kupper, K. C. (2016). Biocontrol ability and putative mode of action of yeasts against Geotrichum citri-aurantii in citrus fruit. Microbiological Research, 188, 72-79.

Fialho, M. B., Toffano, L., Pedroso, M. P., Augusto, F., \& Pascholati, S. F. (2010). Volatile organic compounds produced by Saccharomyces cerevisiae inhibit the in vitro development of Guignardia citricarpa, the causal agent of citrus black spot. World Journal of Microbiology \& Biotechnology, 26(5), 925-932.

Gamagae, S. U., Sivakumar, D., \& Wijesundera, R. L. C. (2004). Evaluation of post-harvest application of sodium bicarbonate-incorporated wax formulation and Candida oleophila for the control of anthracnose of papaya. Crop Protection, 23(7), 575-579.

Ghosh, S. K., Santra, T., \& Chakravarty, A. (2018). Study of yeast flora of fruits and their in vitro screening for antagonistic property against Penicillium digitatum. The Journal of American Science, 14, 36-41.

Habiba, N. R., Noreen, R., Ali, S. A., Hasan, K. A., Sultana, V., Ara, J., \& Ehteshamul-Haque, S. (2019).
Evaluation of biocontrol potential of epiphytic yeast against postharvest Penicillium digitatum rot of stored Kinnow fruit (Citrus reticulata) and their effect on its physiochemical properties. Postharvest Biology and Technology, 148, 38-48.

Kinay, P., Mansour, M. F., Mlikota Gabler, F., Margosan, D. A., \& Smilanick, J. L. (2007). Characterization of fungicide-resistant isolates of Penicillium digitatum collected in California. Crop Protection, 26(4), 647-656.

Kupper, K. C., Lucas, A., Cervantes, L., Klein, M. N., \& Silva, A. C. (2013). Avaliação de microrganismos antagônicos, Saccharomyces cerevisiae e Bacillus subtilis para o controle de Penicillium digitatum. Revista Brasileira de Fruticultura, 35(2), 425-436.

Liu, J., Sui, Y., Wisniewski, M., Droby, S., \& Liu, Y. (2013). Review: utilization of antagonistic yeasts to manage postharvest fungal diseases of fruit. International Journal of Food Microbiology, 167(2), 153-160.

Liu, Y., Wang, W., Zhou, Y., Yao, S., Deng, L., \& Zeng, K. (2017). Isolation, identification and in vitro screening of Chongqing orangery yeasts for the biocontrol of Penicillium digitatum on citrus fruit. Biological Control, 110, 18-24. http://dx.doi.org/10.1016/j.biocontrol.2017.04.002.

Mekbib, S. B., Regnier, T. J. C., \& Korsten, L. (2011). Efficacy and mode of action of yeast antagonists for control of Penicillium digitatum in oranges. Tropical Plant Pathology, 36, 233-240.

Moretto, C., Cervantes, A. L. L., Batista-Filho, A., \& Kupper, K. C. (2014). Integrated control of green mold to reduce chemical treatment in post-harvest citrus fruits. Scientia Horticulturae, 165, 433-438.

Perez, M. F., Ibarreche, J. P., Isas, A. S., Sepulveda, M., Ramallo, J., \& Dib, J. R. (2017). Antagonisticyeastsfor the biological control of Penicillium digitatum on lemons stored under exportconditions. Biological Control, 115, 135-140.

Platania, C., Restuccia, C., Muccilli, S., \& Cirvilleri, G. (2012). Efficacy of killer yeasts in the biological control of Penicillium digitatum on Tarocco orange fruits (Citrus sinensis). Food Microbiology, 30(1), 219-225.

Plaza, P., Usall, J., Teixidó, N., \& Viñas, I. (2004). Effect of water activity and temperature on competing abilities of common postharvest citrus fungi. International Journal of Food Microbiology, 90(1), 75-82. 
Shaner, G., \& Finney, R. E. (1977). The effect of nitrogen fertilization on the expression of slow-mildewing resistance in Knox wheat. Phytopathology, 67(8), 1051-1056.

Sharma, R. R., Singh, D., \& Singh, R. (2009). Biological control of postharvest diseases of fruits and vegetables by microbial antagonists: a review. Biological Control, 50(3), 205-221.

Spadaro, D., \& Droby, S. (2016). Development of biocontrol products for postharvest diseases of fruit: the importance of elucidating the mechanisms of action of yeast antagonists. Trends in Food Science \& Technology, 47, 39-49.

Sun, X., Ruan, R., Lin, L., Zhu, C., Zhang, T., Wang, M., Li, H., \& Yu, D. (2013). Genome wide investigation into DNA elements and $\mathrm{ABC}$ transporters involved in imazalil resistance in Penicillium digitatum. FEMS Microbiology Letters, 348(1), 11-18.

Taqarort, N., Echairi, A., Chaussod, R., Nouaim, R., Boubaker, H., Benaoumar, A. A., \& Boudyach, E. (2008). Screening and identification of epiphytic yeasts with potential for biological control of green mold of citrus fruits. World Journal of Microbiology \& Biotechnology, 24(12), 3031-3038.

Terao, D., Campos, J. S. C., Benato, E. A., \& Hashimoto, J. M. (2015). Alternative strategy on control of postharvest disease of mango (Mangifera indica L.) by use of low dose of Ultraviolet irradiation. Food Engineering Reviews, 7(2), 171-175. http://dx.doi.org/10.1007/s12393-014-9089-4.

Terao, D., Nechet, K. L., Ponte, M. S., Maia, A. H. N., Anjos, V. D. A., \& Halfeld-Vieira, B. A. (2017). Physical postharvest treatments combined with antagonistic yeast on the control of orange green mold. Scientia Horticulturae, 224, 317-323. http://dx.doi.org/10.1016/j. scienta.2017.06.038.

Usall, J., Smilanick, J., Palou, L., Denis-Arrue, N., Teixidó, N., Torres, R., \& Viñas, I. (2008). Preventive and curative activity of combined treatments of sodium carbonates and Pantoea agglomerans CPA-2 to control postharvest green mold of citrus fruit. Postharvest Biology and Technology, 50(1), 1-7. http://dx.doi.org/10.1016/j. postharvbio.2008.03.001.

Wisniewski, M., Droby, S., Norelli, J., Liu, J., \& Schena, L. (2016). Alternative management technologies for postharvest disease control: the journey from simplicity to complexity. Postharvest Biology and Technology, 122, 3-10. http://dx.doi.org/10.1016/j.postharvbio.2016.05.012.

Zhang, H., Zheng, X., \& Xi, Y. (2005). Biological control of postharvest blue mold of oranges by Cryptococcus laurentii (Kufferath) Skinner. Biological Control, 50, 331-342.

Zhu, J., Xie, Q., \& Li, H. (2006). Occurrence of imazalilresistant biotype of Penicillium digitatumin China and the resistant molecular mechanism. Journal of Zhejiang University. Science A, 7(S2), 362-365. http://dx.doi. org/10.1631/jzus.2006.AS0362.

Received: June 06, 2019

Accepted: January 07, 2020

How to cite: Cunha, T., Ferraz, L. P., Sousa-Júnior, G. S., \& Kupper, K. C. (2020). The action of yeast strains as biocontrol agents against Penicillium digitatum in Lima sweet oranges. Citrus Research \& Technology, 41, e1054. https://doi.org/10.4322/crt.18819 